\title{
Predicting mathematics achievement: The role of perceived feedback, teacher support and self-beliefs
}

\author{
Selda Y1ldirım () \\ Bolu Abant İzzet Baysal University, Faculty of Education, Bolu, Turkey, cet_s@ibu.edu.tr \\ https://orcid.org/0000-0003-0535-4353 \\ Hüseyin Hüsnü Yıldırım ${ }^{\circ}$ \\ Bolu Abant İzzet Baysal University, Faculty of Education, Bolu, Turkey, yildirim_h1@ibu.edu.tr \\ https://orcid.org/0000-0001-9924-8281
}

\begin{abstract}
In this study, the mediating roles of perceived teacher support and students' mathematics self-beliefs on the feedback process were investigated in The Programme for International Student Assessment (PISA) context in Turkey. PISA 2012 mathematics scores and questionnaire responses of 4848 15-year-old students were analyzed. Results indicated that perceived feedback was positively related to math selfconcept and negatively related to math anxiety. The investigated indirect effects were partly confirmed: perceived feedback was indirectly related to students' mathematics achievement via perceived teacher support and math self-efficacy. Also, perceived feedback showed an indirect effect on students' mathematics achievement via math anxiety. However, the influences of perceived teacher support on math self-concept and anxiety, and the mediating role of math self-concept were not supported. The results suggest the importance of investigation of mediated effects of teachers' support and students' selfbeliefs between teachers' feedback and mathematics achievement. These relationships may help to understand how teacher's feedback influences mathematics achievement.
\end{abstract}

\section{Matematik başarısını yordama: Algılanan geri bildirim, öğretmen desteği ve öz-inançların rolü}

ÖZ Bu çalışmada, algılanan öğretmen desteğinin ve öğrencilerin matematik ile ilgili öz-inançlarının geri bildirim sürecindeki aracı rolü Uluslararası Öğrenci Değerlendirme Programı (PISA) Türkiye verisi ile incelenmiş̧ir. Türkiye' de 15 yaşındaki 4848 öğrencinin PISA 2012 matematik puanları ve anketlere verdikleri cevaplar analiz edilmiştir. Elde edilen sonuçlar, algılanan geri bildirimin matematik özbenliğiyle pozitif, matematik kaygısıyla da negatif ilişkili olduğunu göstermiştir. Çalışmada incelenen dolaylı etkiler kısmen doğrulanmıştır: algılanan geri bildirim, algılanan öğretmen desteği ve matematik öz-yeterliği aracılığıyla dolaylı olarak matematik başarısıyla ilişkilidir. Ayrıca algılanan geri bildirimin, öğrencilerin matematik başarısıyla, matematik kaygısı aracılı̆̆ıyla da dolaylı olarak ilişkili olabileceği görülmüş̧ür. Bununla birlikte sonuçlar, algılanan öğretmen desteğinin öğrencilerin matematik öz-güveni ve kaygısı üzerindeki etkilerini ve matematik öz-güveninin öğretmen davranışları ve başarı arasındaki aracı rolünü desteklememiştir. Bulgular, öğretmen desteği ve öğrenci öz-inançlarının, öğretmenin geri bildirimi ile matematik başarısı arasındaki aracı rolünün incelenmesinin önemli olabileceğini işaret etmektedir. Bu ilişkiler öğretmen geri bildiriminin matematik başarısını nasıl etkileyebileceğini anlamaya yardımcı olabilir.

Anahtar Algılanan geri bildirim, Algılanan öğretmen desteği, Öz-inançlar, PISA 2012 matematik başarısı

Citation: Yildırım, S. \& Y1ldırım, H.H. (2019). Predicting mathematics achievement: The role of perceived feedback, teacher support and self-beliefs. Turkish Journal of Education, 8(2), 71-85. https://dx.doi.org/10.19128/turje.435345 


\section{INTRODUCTION}

The teachers and the students are the two main actors in the educational stage. Naturally, the influence of these actors' behaviors on one another's endeavors has been an important topic in educational research. The association amongst teachers' feedback and students' motivational beliefs and achievement is one of these kinds of crucial research topics (Heritage, 2010).

Feedback is a critical component of formative assessment. It refers to all kinds of information provided by teachers to students regarding the aspects of their learning (Hattie \& Timperley, 2007; Havnes, Smith, Dysthe, \& Ludvigsen, 2012). The crucial potential of feedback is that it may contribute to reduce the gap between students' current and desired performances (Black \& William, 1998; Black \& William, 2009; Torrence \& Pryor, 1998). There is a growing body of research emphasizing the positive role of teachers' feedback on students' performance in the teaching and learning process (Hattie, 2012).

However, it seems that due to the quite complex nature of relations among teachers' feedback and various student outcomes, there is a need for further research to better understand how feedback influences the outcome (Murtagh, 2014; Rakoczy et al., in press; Thurlings, Vermeulen, Bastiaens, \& Stijnen, 2013). As Thurlings et al. (2013) indicate, it is not only the direct relations to investigate between the feedback and, say, students' mathematics achievement. It is also highly possible that there are some additional variables in the learning environment that may influence and mediate the feedback process. For example, it might be that teachers' feedback increases students' motivation and, hence, their achievement. In such a situation, regression models which account for the mediating roles of variables are required. Mediational models make it possible to see not only the direct relations, but also how teachers' feedback influences student outcomes indirectly via some other variables in the learning environment.

Besides, constructing a mediational model to test requires a convenient theoretical framework. The socio-cultural theory provides such a framework to hypothesize complex relationships among variables related to teachers' feedback and students' achievement (Li, 2016; Thurlings et al., 2013). According to the social cultural perspective, students learn through their social interactions with others (Vygotsky, 1978). Similarly, any feedback received by students may promote student-teacher interactions in the classroom (Skipper \& Dougles, 2015). Feedback to students involves supportive teacher behavior (Torrence \& Pryor, 1998). When teachers use feedback effectively to guide and modify students' learning, they engage more with students; when students receive feedback from their teachers about their learning, they are more likely to perceive their teacher as being more supportive. However, few studies have explored how teachers' feedback influences the students' perception of teacher-student relationships (e.g., Skipper \& Dougles, 2015).

More specifically, research focused on mathematics learning indicates that teachers' feedback may provide opportunities for students to correct their mistakes in mathematics, and may positively affect students' motivational beliefs or achievement (e.g., Harks, Rakoczy, Hattie, Besser, \& Klieme, 2014; James, Amos, \& Adeniyi, 2013; Nunez-Pena, Bono, \& Suares-Pellicioni, 2015; Ofem, Idika, \& Ovat, 2017; Pinger, Rakoczy, Besser, \& Klieme, 2018; Rakoczy, et al., in press). Similarly, research showed that teacher support also influences students' motivation and mathematics achievement (Ahmed, Minnaert, van der Werf, \& Kuyper, 2010; Yıldırım, 2012). In a recent study, Özkal (2018) demonstrates that teachers' supportive behavior positively affects students' motivation to engage in mathematics. Thus, the findings of the literature suggest that perceived feedback and teacher support have the potential to affect the students' motivational beliefs, and their subsequent achievement in mathematics. In line with social cultural perspectives, it is expected that teachers' feedback might influence students' motivational beliefs and achievement indirectly via teacher support. 
In this study, we focused on self-beliefs as components of motivational beliefs. A recent study reported that self-beliefs (such as mathematics self-efficacy, self-concept and anxiety) appear to be strong predictors of mathematics achievement (Stankov \& Lee, 2017). Self-concept and self-efficacy are conceptually different structures about students' own ability (Bong \& Clark, 1999; Bong \& Skaalvik, 2003; Morony, Kleitman, Lee, \& Stankov, 2013). Self-concept describes a student's conception or perception of their abilities and competencies (Schunk \& Pajares, 2005), and is influenced by their experiences and interpretations about social comparisons (Bong \& Skaalvik, 2003), such as students comparing themselves with their classmates. In contrast, self-efficacy refers to a student's cognitive judgment on how they could succeed in a given task (Bandura, 1997; Bong \& Skaalvik, 2003; Pajares, 1996). Research findings suggest a positive relationship between self-efficacy and mathematics achievement (Peters, 2013; Zajacova, Lynch, \& Espenshade, 2005), and self-concept and mathematics achievement (Obilor, 2011; Pipere \& Mierina, 2017; Wang, Osterlind, \& Bergin, 2012). On the other hand, anxiety refers to a student's negative emotional feeling and reaction about performing a task, and is related to the negative forms of self-efficacy and self-concept (Morony et al., 2013). Studies have also shown that anxiety is a negative significant predictor of mathematics achievement (e.g., Metallidou \& Vlachou, 2007; Y1ldırım, 2012). Studies have indicated that teacher feedback to students has an important influence on students' self-beliefs. Students perceiving feedback from their teachers are less likely to be anxious about their mathematics learning (Nunez-Pena et al., 2015; Ugodulunwa \& Okolo, 2015). Similarly, Burnett (2003) indicates that teacher feedback predicts students' mathematics selfconcept positively. Findings of a recent study by Rakoczy et al. (in press) also support the view that self-efficacy beliefs may have a potential to mediate the relationship between teacher's feedback and mathematics achievement. Similarly, previous research indicates that teacher support may be indirectly related to mathematics achievement via self-beliefs (e.g., Ahmed et al., 2010, Yildırım, 2012). Therefore, it is expected that teacher's feedback and support might be both directly, and indirectly, related to mathematics achievement via self-beliefs.

\section{The present study}

Overall, the literature suggests a complex picture of effectiveness regarding the feedback mechanism in learning contexts. Some of the questionnaire items introduced in PISA 2012 are related to students' perceptions of teacher behaviors in the mathematics classroom, and to their mathematics self-beliefs. These items align well with the conceptual framework of this study. Drawing on this data, the purpose of this study is to investigate the relations among perceived feedback, perceived teacher support, selfbeliefs and mathematics achievement. Our primary interest is the underlying mechanism of the feedback process. Therefore, in line with the theoretical and empirical foundations of the relations as explained above, we formulated the following research questions: 1) Is there an effect of perceived feedback on perceived teacher support?; 2) Are there any effects of perceived teacher behavior (feedback and support) on students' math self-beliefs (self-efficacy, self-concept, anxiety)?; 3) Are there any effects of perceived teacher behavior (feedback and support) and students' math self-beliefs (self-efficacy, selfconcept, anxiety) on students' mathematics achievement?; 4) Is there an indirect effect of perceived feedback on math self-beliefs (self-efficacy, self-concept, anxiety) via perceived teacher support?; 5) Are there any indirect effects of perceived feedback on students' mathematics achievement via perceived teacher support and math self-beliefs (self-efficacy, self-concept, anxiety)?; 6) Is there an indirect effect of perceived teacher support on mathematics achievement via math self-beliefs (self-efficacy, selfconcept, anxiety)? The conceptual model presented in Figure 1 summarizes these complex relationships.

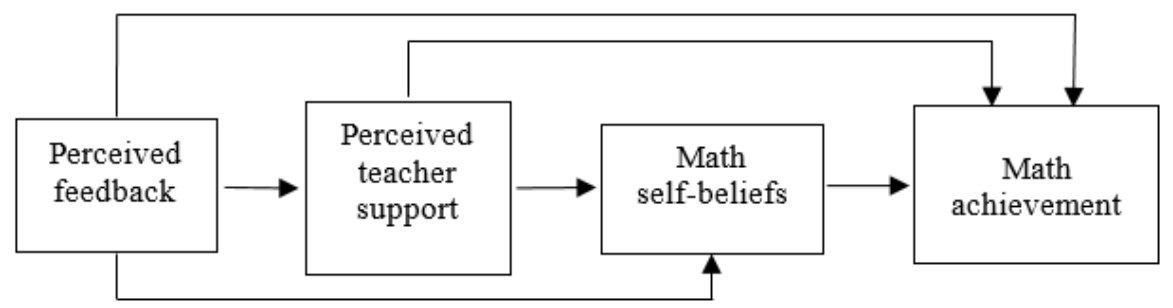

Figure 1. The conceptual model 
Although similar relations have been studied in different learning domains, e.g. reading (Li, 2016), findings on secondary students' mathematics learning are not so abundant (Harks et al., 2014; Pinger et al., 2018). Moreover, these theoretical relations might be influenced by demands of different educational systems. As suggested by Caro, Lenkeit and Kyriakides (2014) some teaching behaviors do not work equally across different populations. Therefore, further research is required to closely examine the effects of teachers' teaching behaviors in different educational settings. We investigated these relations in the context of PISA 2012 mathematics domain in Turkey. Considering Turkey's low mathematics achievement in PISA, the current study may provide some insight into this poor performance. This research may lead to enhance the generalizability of the relations, and to the development of intervention programs related to teachers' feedback practices. Nevertheless, results of this study will not provide causal relationships due to cross-sectional design of PISA studies.

This study also takes into account the gender and SES differences as control variables. In the literature, there is evidence that students' gender may influence their perception of teacher feedback (Carvalho, Santos, Conboy, \& Martins, 2014; Chen, Thompson, Kromrey, \& Chang, 2011; Havnes et al., 2012) and teacher support (Gasser, Grütter, Buholzer, \& Wettstein, 2018; Hajovsky, Mason, \& McCune, 2017). Research also showed that boys report more positive self-beliefs than girls in mathematics (Kvedere, 2014). Similarly, there is also evidence that family-SES may be positively related to students' motivational beliefs (Koutsoulis \& Campbell, 2001) and achievement (Çiftçi \& Cin, 2017; Valero et al., 2015). In addition, Fan, Williams and Corkin (2011) demonstrate that SES related factors may also influence students' perceptions of school climate such as teacher-student relationships.

\section{METHODOLOGY}

\section{Research Design}

In this current study, researchers aim to understand the indirect causal relationship between perceived feedback and mathematics achievement via perceived teacher support and mathematics self-beliefs. Therefore, the research design for this study is correlational research which is analyzed through quantitative methods. This design enables researchers to investigate a theory based relationship between a set of variables (Fraenkel, Wallen, \& Hyun, 2012).

\section{PISA Design}

The Programme for International Student Assessment (PISA) studies is an ongoing study to measure how well students at age 15 are prepared to meet demands of the knowledge society. To this purpose, PISA administers cognitive tests and context questionnaires on the domains of reading, mathematics, problem solving and science. The PISA 2012 study focused on mathematics as a major domain (OECD, 2013).

\section{Participants}

Data from PISA 2012 Turkish sample were used. Specifically, we used the responses of 4848 students from 170 schools. Sampling procedure of PISA studies is a two stage stratified design by which first schools are sampled with probabilities proportional to school sizes, and then students are sampled within the sampled schools with the equal probability cluster sampling (OECD, 2014). Girls comprised 51\% of the sampled students. The grade levels of students varied from 7 th to 12 th (7th grade, .4\%; 8th grade, $2 \%$; 9 th grade, $27.2 \% ; 10$ th grade, $66 \% ; 11$ th grade, $4 \% ; 12$ th grade, $.3 \%)$. 


\section{Variables}

Details on the reliabilities and construct validation of PISA scales are reported in the PISA 2012 Technical Report (OECD, 2014). Constructs studied in this current research are limited by the student questionnaire items from the PISA 2012 study (OECD, 2013).

\section{Mathematics Teacher Behaviors}

Perceived feedback (TCHBEHFA): There are four items in the questionnaire that measure the perception of feedback, or what PISA labels as "formative assessment". Students reported how often (on a four degree Likert scale from" every lesson" to "never or hardly ever") the following four situations happened in their mathematics classes; "the teacher tells me about how well I am doing in my mathematics class", "the teacher gives me feedback on my strengths and weaknesses in mathematics", "the teacher tells us what is expected of us when we get a test, quiz or assignment", and "the teacher tells me what I need to do to become better in mathematics". These items align with the prior research on feedback scale development (e.g., Carvalho et al., 2015).

Perceived teacher support (MTSUP): Similarly, PISA 2012 assessed teacher support via students' responses on how often (on a four degree Likert scale from "every lesson" to "hardly ever") the following five situations happened in their mathematics lessons; "the teacher shows an interest in every students' learning", "the teacher gives extra help when students need it", "the teacher helps students with their learning", "the teacher continues teaching until the students understand", and "the teacher gives students an opportunity to express opinions".

\section{Self-beliefs}

Mathematics self-efficacy (MATHEFF): This scale was constructed using student responses of how confident they felt (on a four degree Likert scale from "very confident" to "not at all confident") about doing the following eight specific tasks; "using a train timetable to work out how long it would take to get from one place to another", "calculating how much cheaper a TV would be after a $30 \%$ discount", "calculating how many square meters of tiles you need to cover a floor", "understanding graphs presented in newspapers", "solving an equation like $3 x+5=17$ ", "the actual distance between two places on a map with a 1: 10.000 scale", and "solving an equation like $2 .(x+3)=(x+3) .(x-3) "$.

Mathematics self-concept (SCMAT): This scale was constructed via student responses to a four degree Likert scale from strongly agree to strongly disagree. The five statements about students' perceived competence were; "I am just not good at mathematics", "I get good grades in mathematics", "I learn mathematics quickly", "I have always believed that mathematics is one of my best subjects", and "In my mathematics class, I understand even the most difficult work".

Mathematics anxiety (ANXMAT): Similarly, this scale was constructed using student responses of how they agree (on a four degree Likert scale from "strongly agree" to "strongly disagree") with the five statements when dealing with mathematics; "I often worry that it will be difficult for me in mathematics classes", "I get very tense when I have to do mathematics homework", "I get very nervous doing mathematics problems", and "I feel helpless when doing a mathematics problem".

\section{Controlling variables students' gender and socio-economic status (SES)}

Considering students' gender and SES in the analyses provided an opportunity to determine the effects of these variables on teacher support, self- beliefs and achievement, and to estimate the relations among the variables controlling for gender and SES. SES (ESCS) as measured in PISA is an index variable constructed using students' parental occupational status and home possessions. 


\section{Student mathematics achievement}

In PISA studies students answered different test booklets and their proficiency scores were obtained using the Rash modeling methodology. There were five proficiency scores (plausible values) in PISA 2012 mathematics data. In the present study, analyses were conducted for each plausible value, and then the statistics obtained from each of the analyses were aggregated to get the final estimates using HLM 6 (Raudenbush, Bryk, \& Congdon, 2004).

\section{Analyses}

The variables we used had missing values (35\% each, due to the rotated design) in PISA 2012 questionnaire data (OECD, 2014). Therefore, prior to conducting the regression analyses, we imputed missing in all variables of interest with the Predictive Mean Matching (PMM) method (Kaplan \& Su, 2016; van Buuren \& Groothuis-Oudshoorn, 2011) using the MICE (multiple imputation by chained equations) package in R (R Development Core Team, 2017). The IEA IDB analyzer (IEA, 2017) was used to estimate the descriptive statistics and the correlations between the variables.

Due to the hierarchical structure (students within schools) of the PISA data, we used the two-level multilevel model using HLM 6 (Raudenbush, Bryk, \& Congdon, 2004). We performed sequential multilevel regression analyses using the centering within context with reintroduction of the subtracted means (group mean centering approach) (Zhang, Zyphur \& Preacher, 2009). Researchers suggest that the group mean centering is appropriate when the primary interest is predictors at level 1 (in this study at student level) (Enders \& Tofighi, 2007). At the student level, variables (perceived feedback, math teacher support, math self-efficacy, math self-concept and math anxiety) and control variables (gender and SES) were inserted into the models. In the analyses, total student weight and school weight were used. All variables were standardized prior to the HLM analyses. Intra-class correlation coefficients (ICC) were estimated using the results of random effect ANOVA (Raudenbush \& Bryk, 2002). Also, the joint significance test was used to calculate the level of statistical significance of the indirect effects (Leth-Steensen \& Gallitto, 2016; Taylor, Mackinnon, \&Tein, 2008). We used the Zhao, Lynch and Chen (2010) classification to test the indirect relations investigated in the study.

\section{FINDINGS}

We first examined the association among the variables. Table 1 reports the zero-order correlations among the scales, means and standard deviations. Then we examined the intra-class correlations for the dependent variables. Results indicated that ICC was $6 \%$ for perceived math teacher support, $19 \%$ for math self-efficacy, $2 \%$ for math self-confidence, $2 \%$ for math anxiety, and $68 \%$ for PISA math achievement.

Table 1.

Descriptive statistics and correlations

\begin{tabular}{lllllllllll}
\hline & \multicolumn{1}{c}{ Variables } & Mean & SD & 1. & 2. & 3. & 4. & 5. & 6. & 7. \\
\hline 1. & Perceived feedback & .18 & 1.03 & & & & & & & \\
2. & Perceived teacher support & .35 & 1.06 & $.48^{* *}$ & & & & & \\
3. & Math self-concept & -.05 & .93 & $.18^{* *}$ & $.08^{* *}$ & & & & \\
4. & Math self-efficacy & -.08 & .86 & $.10^{* * *}$ & $.11^{* *}$ & $.27^{* *}$ & & & \\
5. & Math anxiety & .27 & 1.01 & $-.10^{* *}$ & -.02 & $-.43^{* *}$ & $-.13^{* *}$ & & & \\
6. & Student SES & -1.46 & 1.10 & .01 & .00 & .07 & $.21^{* *}$ & -.05 & & \\
7. & Gender & - & - & .05 & $-.07^{* * *}$ & .04 & $.08^{* *}$ & .00 & .00 & \\
8. & PISA 2012 math achievement & 447.98 & 91.07 & -.01 & .01 & $.17^{* *}$ & $.44^{* *}$ & $-.18^{* *}$ & $.38^{* *}$ & .04 \\
\hline
\end{tabular}


Note. Gender was coded $1=\operatorname{girl}, 2=$ boy. ${ }^{* *} \mathrm{p}<.01 ;{ }^{*} \mathrm{p}<.05$. SES $=$ socio-economic status. All values on index variables have a mean of 0 and standard deviation of 1 across countries. Higher values show support for these constructs. Positive value indicates that when OECD country students are taken into account, students in Turkey on the investigated characteristics have more positive perceptions. For the negative value this is the other way around.

As shown in Table 2, perceived feedback had a positive effect on perceived teacher support. Gender and SES differences were not significantly related to the perceived teacher support. At the student level, $26 \%$ of variance in the perceived teacher support was explained by the perceived feedback. At the student level, $7 \%, 6 \%$, and $5 \%$ of the variance between the students were explained for by math selfefficacy, math concept, and math anxiety respectively.

Table 2.

Results of HLM analyses

\begin{tabular}{|c|c|c|c|c|c|c|c|c|c|c|}
\hline \multirow[t]{2}{*}{ Predictors } & \multicolumn{2}{|c|}{$\begin{array}{c}\text { Perceived } \\
\text { teacher support }\end{array}$} & \multicolumn{2}{|c|}{$\begin{array}{c}\text { Math } \\
\text { self-efficacy }\end{array}$} & \multicolumn{2}{|c|}{$\begin{array}{c}\text { Math } \\
\text { self-concept }\end{array}$} & \multicolumn{2}{|c|}{$\begin{array}{l}\text { Math } \\
\text { anxiety }\end{array}$} & \multicolumn{2}{|c|}{$\begin{array}{c}\text { PISA } 2012 \\
\text { math achievement }\end{array}$} \\
\hline & $\beta$ & SE & $\beta$ & SE & $\beta$ & SE & $\beta$ & $\mathrm{SE}$ & $\beta$ & SE \\
\hline Gender & $-.06^{*}$ & .02 & $.10^{* *}$ & .02 & .02 & .03 & .00 & .03 & $.08^{* * *}$ & .02 \\
\hline SES & -.02 & .02 & $.12^{* *}$ & .02 & .03 & .02 & .03 & .02 & $.04^{* *}$ & .02 \\
\hline Perceived feedback & $.50^{* * *}$ & .02 & .04 & .02 & $.15^{* *}$ & .03 & $-.13^{* *}$ & .02 & .00 & .01 \\
\hline Perceived teacher support & & & $.14^{* *}$ & .03 & .03 & .03 & .03 & .03 & -.01 & .01 \\
\hline Math anxiety & & & & & & & & & $-.06^{* *}$ & .01 \\
\hline Math self-efficacy & & & & & & & & & $.15^{* *}$ & .02 \\
\hline Math self-concept & & & & & & & & & .03 & .01 \\
\hline $\mathrm{R}^{2}$ student level & & .26 & & .07 & & .06 & & .05 & & .15 \\
\hline
\end{tabular}

As shown in Table 2, perceived teacher support and perceived feedback were significant positive predictors of math self-efficacy and math self-concept respectively; however, perceived feedback was a significant negative predictor of math anxiety. The results of the present study suggest that the perceived teacher support mediates the relationship between perceived feedback and math self-efficacy. The results did not support the indirect effect of perceived feedback on math self-concept and anxiety through perceived teacher support. Boys reported higher levels of math self-efficacy beliefs. Gender differences were not significantly related to math self-concept and anxiety. SES was a positive predictor of math self-efficacy. Math self-efficacy and math anxiety are significant predictors; perceived feedback, perceived teacher support, and math self-concept are non-significant predictors of PISA math achievement. At the student level, $15 \%$ of the variance explained for PISA math achievement in the presence of the gender and SES. The results related to indirect relations are demonstrated in Figure 2. In the joint significance test, there is a mediated effect if each of the paths in the mediation is statistically significant (Taylor et al., 2008). As shown in Figure 2, perceived feedback was a significant predictor of perceived teacher support, and perceived teacher support was a significant predictor of math selfefficacy; similarly, math self-efficacy was a significant predictor of PISA math achievement. Therefore, as shown in Figure 2, the results indicate the mediational role of perceived teacher support and math self-efficacy between the perceived feedback and PISA math achievement. Furthermore, the results of the present study suggest that there is only an indirect relationship between perceived teacher support and PISA math achievement through math self-efficacy. The results also suggest that perceived feedback is indirectly related to PISA math achievement through math self-efficacy and math anxiety. The results have not supported the indirect effect of perceived feedback on math achievement through math self-concept. Student level $\mathrm{R}^{2}$ values and only significant paths $\left({ }^{* *} \mathrm{p}<.01\right)$ are presented in Figure 2 .

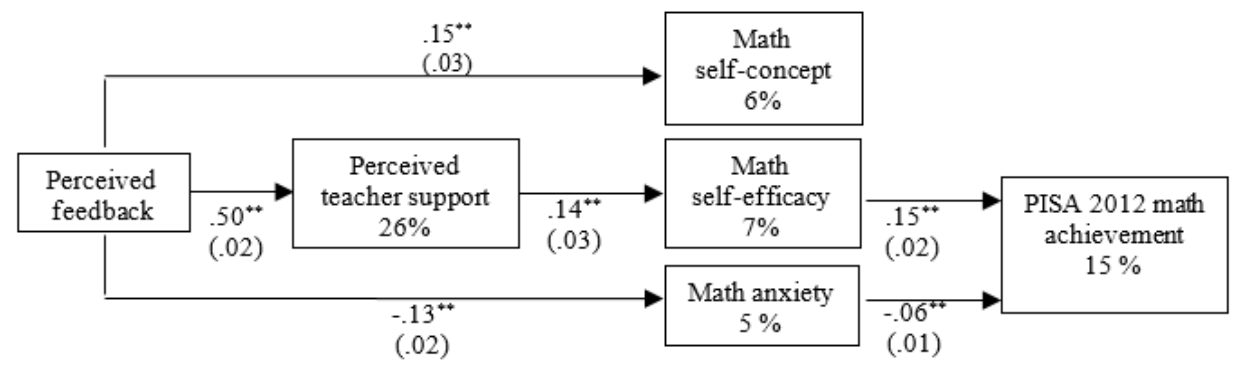

Figure 2. Regression coefficients and standard errors in conceptual model 


\section{DISCUSSION and CONCLUSION}

In the present study, we examined the role of perceived feedback, teacher support and self-beliefs in predicting students' achievement in the domain of mathematics. The results revealed that students' perceived feedback influence their perception of teacher support and, thus, their math self-efficacy. The results also showed that perceived feedback has an indirect positive effect on mathematics achievement via math self-efficacy and anxiety. Contrary to our expectations, perceived feedback has neither been indirectly related to math self-concept and anxiety via perceived teacher support nor to mathematics achievement via math self-concept.

The finding on the positive relationship between perceived feedback and perceived teacher support is consistent with the social cognitive theory which supports the view that feedback has a potential role in increasing student-teacher relationships in the learning environment (e.g. Li, 2016; Skipper \& Dougles, 2015; Torrence \& Pryor, 1998). This finding shows the importance of examining how perceived feedback relates to perceived teacher support in understanding the feedback process.

Regarding the predictors of mathematics self-beliefs, we found that perceived feedback is directly related to math anxiety and math self-concept. Although the models predicting motivational beliefs in this study explain small amount of variance, the result is in line with studies which indicate that teachers' feedback influence students' motivational beliefs. For example, this finding supports Nunez-Pena et al. (2015) and Ugodulunwa and Okolo (2015) studies both of which indicate that teacher feedback may reduce anxiety in mathematics. Similarly, this finding parallels the work of Burnett (2003) whose research findings suggest a positive relationship between self-concept and teacher feedback. One of the considerable findings in this study is that feedback as perceived by students has a direct effect on students' math self-concept, while it is only indirectly related, via perceived teacher support to students' math self-efficacy. This finding may be explained by the nature of self-concept, which is mostly based on social comparisons (Bong \& Skaalvik, 2003). To be more specific, we know that in a competitive learning environment, secondary schools' mathematics teachers are more likely to give feedback to their students by comparing their performance to the performance of other students than to a predefined content-related criterion (Harks et al., 2014). In Turkey, due to the national exams necessary to enter high schools and universities, the educational system is highly competitive. Thus, due to this structure, students may perceive their teachers' feedback on how well they are doing in their math class from a perspective of their relative position to their classmates. Consequently, this perception may show itself through a student's self-concept of how good they think they are at mathematics, thereby revealing a direct relationship between the perceived feedback and math self-concept.

In the same manner, when it comes to students' task-specific mathematics confidence (i.e. their selfefficacy), teachers' actual learning support as perceived by students (i.e. perceived teacher support) accounts for any possible direct relation between perceived feedback and math self-efficacy. In other words, perceived feedback may only be indirectly related to students' math self-efficacy in the extent to which it includes task specific statements. In view of that, giving well defined mathematics tasks may provide a better context to reveal the association among students' perceived feedback, teacher support, and their math self-efficacy. Therefore, in Turkey, the nature and quality of mathematics teachers' feedback, and its' effect on different types of self-beliefs needs to be detailed further.

The diversity among the nature of self-efficacy, self-concept and anxiety may also partly explain the mediating role of teacher support in the model of this study. As stated before, self-efficacy as measured in PISA is more related to cognitive judgments based on specific math tasks, whereas self-concept and anxiety are more connected to an affective evaluation of students themselves. Teacher support in this study only mediates feedback on self-efficacy. This means that when the students' perceived feedback is taken into account, mathematics teachers' supportive behaviors are hardly related to students' affective or emotional beliefs (i.e., self-concept and anxiety). 
In regards to the role of perceived teacher support on anxiety, there are studies with which the result of the present study is in line. For example, Taylor and Fraser (2003) and Yildırım (2012) indicate that perceived teacher support may not be effective in reducing high school students' mathematics anxiety. However, there are some contradictory results in the literature as well. For example, in a study in the Netherlands by Ahmed et al. (2010), findings suggest that teacher support decreases junior secondary school students' anxiety level, and increases their self-competence in the mathematics domain. Therefore, it is possible to claim that cultural differences among countries should also be taken into account in order to further detail the complex relationship among teachers' feedback and various types of student self-beliefs.

Concerning self-belief predictors of PISA 2012 mathematics achievement, students' math self-efficacy and anxiety in our study proved to be significant predictors of achievement. In line with previous research (Zajacova et al., 2005) the effect of anxiety on mathematics achievement was small in comparison to the effect of math self-efficacy. Additionally, self-concept did not predict the Turkish students' mathematics achievement. In other words, math self-concept did not mediate the feedback process on achievement. This finding, however, is contrary to findings by Tosto, Asbury, Mazzocco, Petrill and Kovas (2016), whose research suggests that in the United Kingdom, academic self-concept of pupils at age 16 was a mediating variable between perceptions of classroom environment and mathematics achievement. The present results demonstrate the complexity of the mediational role of teacher's behavior in classrooms and students' self-beliefs between perceived feedback and achievement.

Despite the fact that there are studies that indicate the direct influence of formative assessment (e.g., $\mathrm{Li}$, 2006) and support (e.g., Ahmed et al., 2010) on achievement, in this present study, both perceived feedback and perceived teacher support were not directly related to mathematics achievement. However, findings regarding the mediating role of teacher support, math self-efficacy and anxiety supported previous work of Thurlings et al. (2013), which indicates the existence of variables that mediate the feedback process. The results of this study show that mathematics achievement is fostered by different indirect effects.

Prior research has demonstrated that the perception of teacher-student relationships has a mediating role between formative assessment and students' PISA reading achievement $(\mathrm{Li}, 2016)$. Similarly, it appears that mathematics is yet an additional subject in which an indirect effect of feedback on mathematics achievement via perception of teacher support exists. Results support the expectation that students receiving feedback from teacher about their mathematics learning are more likely to perceive their teacher as being supportive. This supportive relationship in the classroom influences the students' math self-efficacy and, hence, their mathematics learning.

Similarly, the finding regarding the mediating role of self-efficacy is in line with Rakoczy et al. (in press), whose research indicates that, in Germany, students' self-efficacy has the potential to mediate the relationship between formative assessment and mathematics achievement. In our study, extending the prior research, we found that anxiety might also be a mediating variable between perceived feedback and mathematics achievement. Therefore, integrating the mediational role of anxiety into models of feedback process would be an important issue to consider in future research.

Research has shown that the effects of teachers' classroom practices on learning outcomes can be lower in developing countries (Santibanez \& Fagioli, 2016). Turkey has a low socio-economic index among the participating countries in PISA. It appears that Turkey is one of the developing countries in which teaching practices related to formative assessment may have had low impact on students' self-beliefs and PISA mathematics achievement. The effects of teacher behavior at school or class level may be more related to student outcomes (e.g., Mikk, Krips, Säälik, \& Kalk, 2016). In future research, it would be worthwhile to examine the effects of teachers' feedback and support on student outcomes at class level using teacher responses. 
This study has limitations that need to be addressed. Firstly, this research was cross-sectional therefore, we cannot indicate any causal effects. In future research, longitudinal studies may provide causal relations about the underlying mechanism of feedback process. Secondly, this study was restricted to the Turkish sample. Future research could also extend this work by examining different cultures. Finally, we acknowledge that teacher feedback is more complex than what was measured in PISA. In PISA 2012 teachers' feedback was measured via students' perceptions. Although previous research indicates that the students' reports are useful measures for teachers' teaching practices (Burnett, 2003; Li, 2016), actual teacher feedback may have different effects than perceived teacher feedback. Therefore, future studies should investigate teachers' feedback through classroom observations and students' perception of teacher feedback together.

In conclusion, we were able to show that perceived teacher feedback influences the perception of teacher support and, thus, students' self- beliefs and mathematics achievement, even though our results partly met our expectations. Due to the fact that students who received feedback from their teacher are more likely to perceive their teacher as being supportive, enhancing feedback practices would contribute to student learning. Teachers need to consider the importance of their feedback practices, and the mediating effects of their behaviors and students' self-beliefs on students' mathematics learning.

\section{REFERENCES}

Ahmed, W., Minnaert, A., van der Werf, G., \& Kuyper, H. (2010). Perceived social support and early adolescents' achievement: The mediational roles of motivational beliefs and emotions. Journal of Youth Adolescence, 39, 36-46. https://doi.org/10.1007/s10964-008-9367-7

Bandura, A. (1997). Self-efficacy: The exercise of control. New York, NY: Freeman.

Black, P. \& Wiliam, D. (2009). Developing the theory of formative assessment. Educational Assessment, Evaluation and Accountability, 21(1), 5-31. https://doi.org/10.1007/s11092-008-9068-5

Black, P., \& Wiliam, D. (1998). Assessment and classroom learning. Assessment in Education: Principles, Policy \& Practice, 5, 7- 68. https://doi.org/10.1080/0969595980050102

Bong, M. \& Clark, R. E. (1999). Comparison between self-concept and self-efficacy in academic motivation research. Educational Psychologist, 34(3), 139-153. https://doi.org/10.1207/s15326985ep3403_1

Bong, M., \& Skaalvik, E. M. (2003). Academic self-concept and self-efficacy: How different are they really? Educational Psychology Review, 15, 1-40. https://doi.org/10.1023/A:1021302408382

Burnett, P. C. (2003). The impact of teacher feedback on student self-talk and self-concept in reading and mathematics. The Journal of Classroom Interaction, 38, 11-16.

Caro, D. H., Lenkeit, J. \& Kyriakides, L. (2014). Teaching strategies and differential effectiveness across learning contexts: Evidence from PISA 2012. Studies in Educational Evaluation, 49, 30-41. https://doi.org/10.1016/j.stueduc.2016.03.005

Carvalho, C., Conboy, J., Santosa, J., Fonseca, J., Tavares, D., Martinsa, D., Salema, M.H., Fiuzad, E., \& Gama, A.P. (2015). An integrated measure of student perceptions of feedback, engagement and school identification. Procedia - Social and Behavioral Sciences 174, 2335-2342. https://doi.org/10.1016/j.sbspro.2015.01.896

Carvalho, C., Santos, J., Conboy, J., \& Martins, D. (2014). Teachers' feedback: Exploring Differences in Students' Perceptions. Procedia- Social and Behavioral Sciences, 159, 169-173. https://doi.org/10.1016/j.sbspro.2014.12.351

Chen, Y., Thompson, M. S., Kromrey, J. D., \& Chang, G. H. (2011). Relations of student perceptions of teacher oral feedback with teacher expectancies and student self-concept. The Journal of Experimental Education, 79(4), 452-477. https://doi.org/10.1080/00220973.2010.547888

Çiftçi, Ş. K., \& Cin, F. M. (2017). The effect of socioeconomic status on students' achievement. In: Karadag E. (eds), The factors effecting student achievement (pp.171-181). Springer, Cham. https://doi.org/10.1007/978-3-319-56083-0_10

Enders, C.K., \& Tofighi, D. (2007). Centering predictor variables in cross-sectional multilevel models: A new look at an old issue. Psychological Methods, 12, 121-138. https://doi.org/10.1037/1082-989X.12.2.121 
Fan, W., Williams, C. M., \& Corkin, D. M. (2011). A multilevel analysis of student perceptions of school climate: The effect of social and academic risk factors. Psychology in the Schools, 48(6), 632-647. https://doi.org/10.1002/pits.20579

Fraenkel, J. R., Wallen, N. E., \& Hyun, H. H. (2012). How to design and evaluate research in education (8th edition). New York: McGraw Hill.

Gasser, L., Grütter, J., Buholzer, A., \& Wettstein, A. (2018). Emotionally supportive classroom interactions and students' perceptions of their teachers as caring and just. Learning and Instruction, 54, 82-92. https://doi.org/10.1016/j.learninstruc.2017.08.003

Hajovsky, D. B., Mason, B. A., \& McCune, L. A. (2017). Teacher-student relationship quality and academic achievement in elementary school: A longitudinal examination of gender differences. Journal of School Psychology, 63, 119-133. doi: 10.1016/j.jsp.2017.04.001

Harks, B., Rakoczy, K., Hattie, J., Besser, M., \& Klieme, E. (2014). The effects of feedback on achievement, interest and self-evaluation: the role of feedback's perceived usefulness. Educational Psychology, 34(3), 269-290. https://doi.org/10.1080/01443410.2013.785384

Hattie, J. (2012). Visible learning for teachers: Maximizing impact on learning. Oxford, UK: Routledge.

Hattie, J., \& Timperley, H. (2007). The power of feedback. Review of Educational Research, 77(1), 81-112. https://doi.org/10.3102/003465430298487

Havnes, A., Smith, K., Dysthe, O. \& Ludvigsen, K. (2012). Formative assessment and feedback: Making learning visible. Studies in Educational Evaluation, 38, 21-27. https://doi.org/10.1016/j.stueduc.2012.04.001

Heritage, M. (2010). Formative assessment: Making it happen in the classroom. Thousand Oaks, CA: Corwin Press.

IEA (2017). Help Manual for the IEA IDB Analyzer (Version 4.0). Hamburg, Germany. Available from www.iea.nl/data.html.

James, A.O., Amos, O.A. \&Adeniyi, A.A. (2013). Effect of formative testing with feedback on students' achievement in junior secondary school mathematics in Onda State Nigeria. International Education Research, 1(2), 8-20. https://doi.org/10.12735/ier.v1i2p08

Kaplan, D., \& Su, D. (2016). On matrix sapling and imputation of context questionnaires with implications for the generation of plausible values in large-scale assessments. Journal of Educational and Behavioral Statistics, 41, 57-80. https://doi.org/10.3102/1076998615622221

Koutsoulis, M. K., \& Cambell, J. R. (2001). Family processes affect students' motivation, and science and math achievement in Cypriot high schools. Structural Equation Modeling, 8(1), 108-127. https://doi.org/10.1207/S15328007SEM0801_6

Kvedere, L. (2014). Mathematics self-efficacy, self-concept and anxiety among 9th grade students in Latvia. Procedia - Social and Behavioral Sciences, 116, 2687-2690. https://doi.org/10.1016/j.sbspro.2014.01.636

Leth-Steensen, C., \& Gallitto, E. (2016). Testing mediation in structural equation modeling: The effectiveness of the test of joint significance. Educational and Psychological Measurement, 76(2), 339-351. https://doi.org/10.1177/0013164415593777

Li, H. (2016). How is formative assessment related to students' reading achievement? Findings from PISA 2009. Assessment in Education: Principles, Policy \& Practice, 23(4), 473-494. https://doi.org/10.1080/0969594X.2016.1139543

Metallidou, P., \& Vlachou, A. (2007). Motivational beliefs, cognitive engagement, and achievement in language and mathematics in elementary school children. International Journal of Psychology, 42, 2-15. https://doi.org/10.1080/00207590500411179

Mikk, J., Krips, H., Säälik, Ü., \& Kalk, K. (2016). Relationships between student perception of teacher-student relations and PISA results in mathematics and science. International Journal of Science and Mathematics Education, 14, 1437-1454. https://doi.org/10.1007/s10763-015-9669-7

Morony, S., Kleitman, S., Lee, Y. P., \& Stankov, L. (2013). Predicting achievement: Confidence vs self-efficacy, anxiety, and self-concept in Confucian and European countries. International Journal of Educational Research, 58, 79-96. https://doi.org/10.1016/j.ijer.2012.11.002

Murtagh, L. (2014). The motivational paradox of feedback: teacher and student perceptions. The Curriculum Journal, 25(4), 516-541. https://doi.org/10.1080/09585176.2014.944197

Nunez-Pena, M. I., Bono, R., \& Suares-Pellicioni, M. (2015). Feedback on students' performance: A possible way of reducing the negative effect of math anxiety in higher education. International Journal of Educational Research, 70, 80-87. https://doi.org/10.1016/j.ijer.2015.02.005

Obilor, I. E. (2011). Relationship between self-concept and mathematics achievement of senior secondary students in Port Harcourt. Journal of Educational and Social Research, 1(4), 39-46.

OECD (2013). PISA 2012 Assessment and Analytical Framework: Mathematics, Reading, Science, Problem Solving and Financial Literacy. OECD Publishing. https://doi.org/10.1787/9789264190511-en

OECD (2014). PISA 2012 Technical Report. OECD Publishing. 
Ofem, U. J., Idika, D. O., \& Ovat, S. V. (2017). Effect of diagnostic and feedback assessment approaches in enhancing achievement in mathematics among secondary school students in Calabar Municipality. International Journal of Scientific Research in Education, 10(2), 221-227.

Özkal, N. (2018). Relationship between students' math engagement and math teachers' motivational support. Turkish Journal of Education, 7(2), 86-98. https://doi.org/10.19128/turje.339944

Pajares, F. (1996). Self-efficacy beliefs in academic settings. Review of Educational Research, 66, 543-578. https://doi.org/10.3102/00346543066004543

Peters, M. L. (2013). Examining the relationships among classroom climate, self-efficacy, and achievement in undergraduate mathematics: A multilevel analysis. International Journal of Science and Mathematics Education, 11, 459-480. https://doi.org/10.1007/s10763-012-9347-y

Pinger, P., Rakoczy, K., Besser, M., \& Klieme, E. (2018). Implementation of formative assessment-effects of quality of programme delivery on students' mathematics achievement and interest. Assessment in Education: $\quad$ Principles, $\quad$ Policy \& $\quad$ Practice, $\quad 25(2), \quad 160-182$. https://doi.org/10.1080/0969594X.2016.1170665

Pipere, A., \& Mierina, I. (2017). Exploring non-cognitive predictors of mathematics achievement among 9th grade students. Learning and Individual Differences, 59, 65-77. https://doi.org/10.1016/j.lindif.2017.09.005

R Development Core Team (2017). R: A language and environment for statistical computing. Vienna, Austria, The $\mathrm{R}$ foundation of statistical computing.

Rakoczy, K., Pinger, P., Hochweber, J., Klieme, E., Schütze, B., \& Besser, M. (in press). Formative assessment in mathematics: Mediated by feedback's perceived usefulness and students' self-efficacy. Learning and Instruction. https://doi.org/10.1016/j.learninstruc.2018.01.004

Raudenbush, S. W., \& Bryk, A. S. (2002). Hierarchical linear models: Applications and data analysis methods (2nd ed.). Newbury Park, CA: Sage.

Raudenbush, S. W., Bryk, A. S, \& Congdon, R. (2004). HLM 6 for Windows [Computer software]. Lincolnwood, IL: Scientific Software International, Inc.

Santibanez, L., \& Fagioli, L. (2016). Nothing succeeds like success? Equity, student outcomes, and opportunity to learn in high- and middle-income countries. International Journal of Behavioral Development, 4 (6), 517 525. https://doi.org/10.1177/0165025416642050

Schunk, D. H., \& Pajares, F. (2005). Competence perceptions and academic functioning. In A. J. Elliot \& C. S. Dweck (Eds.), Handbook of competence and motivation (pp. 85-104). New York: Guilford Press.

Skipper, Y., \& Dougles, K. (2015). The influence of teacher feedback on children's perceptions of student-teacher relationships. British Journal of Educational Psychology, 85, 276-288. https://doi.org/10.1111/bjep.12070

Stankov, L., \& Lee, J. (2017). Self-beliefs: strong correlates of mathematics achievement and intelligence. Intelligence, 61, 11-16. https://doi.org/10.1016/j.intell.2016.12.001

Taylor, A. B., Mackinnon, D. P., \& Tein, J-Y. (2008). Tests of the three-path mediated effect. Organizational Research Methods, 11(2), 241-269. https://doi.org/10.1177/1094428107300344

Taylor, B. A., \& Fraser, B. J. (2003, April). The influence of classroom environment on high school students' mathematics anxiety. Paper presented at the annual meeting of the American Educational Research Association, Chicago, IL.

Thurlings, M., Vermeulen, M., Bastiaens, T., \& Stijnen, S. (2013). Understanding feedback: A learning theory perspective. Educational Research Review, 9, 1-15. https://doi.org/10.1016/j.edurev.2012.11.004

Torrence, H., \& Pryor, J. (1998). Investigating Formative Assessment: teaching, learning and assessment in the classroom. Philadelphia, PA Open University Press.

Tosto, M. G., Asbury, K., Mazzocco, M. M. M., Petrill, S. A., \&Kovas, Y. (2016). From classroom environment to mathematics achievement: The mediating role of self-perceived ability and subject interest. Learning and Individual Differences, 50, 260-269. https://doi.org/10.1016/j.lindif.2016.07.009

Ugodulunwa, C. A., \& Okolo, U. P. (2015). Effects of formative assessment on mathematics test anxiety and performance of senior secondary school students in Jos, Nigeria. IOSR Journal of Research \& Method in Education, 5(2), 38-47. https://doi.org/10.9790/7388-05223847

Valero, P., Graven, M., Jurdak, M., Martin, D., Meaney, T., Penteado, M. (2015). Socioeconomic influence on mathematical achievement: What is visible and what is neglected. In: Cho S. (eds), The Proceedings of the 12th International Congress on Mathematical Education. (pp. 285-301). Springer, Cham. https://doi.org/10.1007/978-3-319-12688-3_19

van Buuren, S., \& Groothuis-Oudshoorn, K. (2011). MICE: Multivariate imputation by chained equations in R. Journal of Statistical Software, 45(3), 1-67. https://doi.org/10.18637/jss.v045.i03

Vygotsky, L. (1978). Mind in society: The development of higher psychological processes. Cambridge, MA: Harvard University Press.

Wang, Z. E., Osterlind, S. J., \& Bergin, D. A. (2012). Building mathematics achievement models in four countries using TIMSS 2003. International Journal of Science and Mathematics Education, 10, 1215-1242. https://doi.org/10.1007/s10763-011-9328-6 
Y1ldırım, S. (2012). Teacher support, motivation, learning strategy use, and achievement: a multilevel mediation model. The Journal of Experimental Education, $150-172$. https://doi.org/10.1080/00220973.2011.596855

Zajacova, A., Lynch, S. M., \& Espenshade, T. J. (2005). Self-efficacy, stress, and academic success in college. Research in Higher Education, 46(6), 677-706. https://doi.org/10.1007/s11162-004-4139-z

Zhang, Z., Zyphur \& M.J., \& Preacher, K.J. (2009). Testing multilevel mediation using hierarchical linear models problems and solutions. Organizational Research Methods, 12, 695-719. https://doi.org/10.1177/1094428108327450

Zhao, X., Lynch Jr. J. G., \& Chen, Q. (2010). Reconsidering Baron and Kenny: Myths and truths about mediation analysis. Journal of Consumer Research, 37, 197-206. https://doi.org/10.1086/651257 


\section{TÜRKÇE GENIȘLETILMIŞ ÖZET}

Öğretmen davranışları ile öğrenme çıtıları arasındaki ilişkiler incelendiğinde, öğretmenlerin öğrencilere geri bildirim vermesinin öğrencilerin motivasyonel inançlarını ve başarılarını etkileyen önemli bir faktör olduğu görülmektedir. Geri bildirim öğrencilerin var olan bilgileri ve olması gereken bilgileri arasındaki farkı azaltmaya katkıda bulunmaktadır. Geri bildirim ile öğrenci başarısı arasındaki ilişkide etkili olabilecek başka değişkenler de olabilir ve bu değişkenlerin rolü sosyal kültürel teori çerçevesinde incelenebilir. Sosyal kültürel teoriye göre, öğrenciler başkalarıyla sosyal etkileşimleri aracılı̆̆ıyla öğrenirler. Benzer şekilde, öğretmenler, öğrencilerin öğrenmelerini yönlendirmek ve değiştirmek için geri bildirimi etkin bir şekilde kullandıklarında, öğrencilerle olan etkileşimleri de artar. $\mathrm{Bu}$ etkileşim öğretmenlerin destekleyici davranışlarını da içerir. Geri bildirim alan öğrenciler, öğretmenlerinden daha fazla destek almış olurlar. Öğretmenin geri bildirimi ve desteği öğrenci motivasyonu veya başarı üzerinde etkili olabilir. Örneğin, öğretmenin geri bildirimi, öğretmen desteğini artırırken, motivasyon aracılığıyla da başarı üzerinde etkili olabilir. Özellikle ortaokul matematik başarısı ile ilgili olarak bu ilişkilerin araştıııldığı çalışma sayısı oldukça sınırlıdır. Bu nedenle bu çalışmada öğretmen desteği ile birlikte, öğrenci motivasyonunun geri bildirim ile matematik başarısı arasındaki aracı rolü PISA 2012 bağlamında incelenmiştir. Literatür öğrencilerin matematik özyeterliği, öz-benliği ve kaygısının matematik başarısı üzerinde etkili olabilecek en önemli öz-inançlar olduğunu gösterdiğinden bu çalışmada bu üç değişkenin arac1 rolü incelenmiştir. Bu çalışmanın bulguları matematik öğrenme ortamlarındaki öğretmen davranışlarının etkilerinin anlaşılmasını sağlayabilir. Türkiye'nin PISA' daki düşük matematik başarısı göz önünde bulundurulduğunda, mevcut çalışma bu zayıf performansa farklı bir bakış açısı sağlayabilir.

Çalışmadaki değişkenler, PISA 2012 öğrenci anketlerinde yer alan maddelerle sinırlıdır. Bu değişkenlerden elde edilen verinin güvenirliği ve yapı geçerliği PISA 2012 teknik raporlarında detaylı bir şekilde yer almaktadır. PISA 2012 verisinin, önce okulların sonra okullardan öğrencilerin rastgele seçilerek elde edildiği, çok düzeyli bir örneklem yapısı vardır. Ayrıca, PISA sonuçları, Türkiye'de öğrencilerin matematik öz-yeterliği ve matematik başarıları arasındaki farklılığın okul düzeyindeki farklılıktan da kaynaklanabileceğini göstermiştir. Bu nedenle, bu çalışmada analizler okul düzeyi ve öğrenci düzeyi dikkate alınarak yapılmıştır. Ayrıca, öğrenci cinsiyeti ve sosyo-ekonomik statüsü de incelenen değişkenlerle ilişkili olabileceğinden kontrol değişkeni olarak analizlerde yer almıştır. Analizlerde, algılanan geri bildirim, algılanan öğretmen desteği, öz-yeterlik, öz-benlik, kaygı, cinsiyet ve sosyo-ekonomik statü değişkenleri ve matematik puanları kullanılmıştır.

Elde edilen sonuçlarda, sosyal kültürel teori ile uyumlu olarak algılanan geri bildirimin, algılanan öğretmen desteği üzerinde olumlu bir etkisinin olabileceği görülmektedir. Ancak, algılanan geri bildirim ve matematik başarısı arasındaki ilişkilerde algılanan öğretmen desteğinin ve öğrencilerin özinançlarının aracı rolü kısmen doğrulanmıştır. Algılanan geri bildirimin, öğrencilerin matematik özbenliği ve matematik kaygıları üzerinde istatistiksel olarak anlamlı bir etkisinin olabileceği görülmüştür. Öz-benlik, öğrencilerin kendi matematik başarılarını sınıf arkadaşlarının başarılarıyla karşılaştırmalarından etkilenen bir inançtır. Türkiye'deki sınav sisteminden dolayı öğretmenlerin öğrencilere verdikleri geri bildirimler, öğrencilerin arkadaşlarının matematik performanslarıyla karşılaştırılmasını içerebilir. Bu nedenle, algılanan geri bildirim ile öz-benlik doğrudan ilişsili bulunmuş olabilir. Benzer şekilde kaygı da öz-benliğin olumsuz şekli olduğundan algılanan geri bildirim ile arasında negatif bir ilişki elde edilmiş olabilir. Bununla birlikte, algılanan geri bildirimin matematik özyeterliği üzerinde doğrudan bir etkisi görülmezken, algılanan öğretmen desteği aracılığıyla dolaylı bir etkisi vardır. Matematik öz-yeterliği ise öğrencilerin belirli matematik konularında kendilerini yeterli görüp görmedikleri ile ilgilidir. Bu nedenle, geri bildirimin, öz-yeterlik özerinde etkili olabilmesi için daha fazla öğretmen-öğrenci etkileşimi gerekiyor olabilir. Öğretmenin geri bildirimi her ne kadar öğretmenin öğrencilere olan desteğini artırsa da, sonuçlarda algılanan öğretmen desteğinin öz-benlik ve kayg1 üzerinde etkisi olmamıştır. Öğretmen desteğinin öz-inançlar üzerindeki rolünün de farklı olabileceği görülmektedir. Matematik öğretmenlerinin desteği, öğrencilerin matematik konularındaki yeterliklerini bilişsel olarak değerlendirmeyi içeren öz-yeterlik inançları üzerinde etkili olurken, daha 
duyuşsal yargıları içeren öz-benlik ve kaygı gibi öz-inançlar üzerinde etkili olmayabilir. Bu nedenle, geri bildirim ve öğretmen desteğinin farklı öz-inançlar üzerindeki etkilerinin yapılacak olan çalışmalarda araştırılması daha detaylı genellenebilir sonuçlar ortaya çıkarabilir. Matematik başarısının istatistiksel olarak anlamlı yordayıcıları ise matematik öz-yeterliği ve matematik kaygısı olmuştur. Elde edilen sonuçlar, algılanan geri bildirim ve matematik başarısı arasındaki ilişkide, algılanan öğretmen desteğinin, öz-yeterliğin ve kaygının aracı rolünün olabileceği varsayımını desteklemiştir. Özetle, sonuçlar, öğretmenin geri bildirimi sonucunda öğrencilerin öğretmenlerini daha destekleyici olarak algılayabileceklerini ve bunun sonucu olarak matematik öz-yeterliklerinin ve başarılarının artabileceğini göstermiştir. Benzer şekilde, her ne kadar kaygının başarı üzerindeki etkisi az bulunmuş olsa da, öğretmenlerin geri bildiriminin öğrencilerin matematik kaygısını azaltma, bunun sonucu olarak da matematik başarıları artırma gibi bir sonucu olabilir. 